\title{
UNESCO Dünya Miras Listesi ve UNESCO Geçici Listelerinde Köprü Mirası ve Türkiye UNESCO Geçici Listesine Yönelik Öneriler
}

\section{UNESCO World Heritage List and Bridge Heritage in UNESCO Tentative Lists and Suggestions for UNESCO Tentative List of Turkey}

\author{
Veysel ÖZBEY \\ Doktora Öğrencisi, Çukurova Üniversitesi Fen Bilimleri Enstitüsü Mimarlık Anabilim Dalı \\ email: veyselozbey@gmail.com (DORCID ID: https://orcid.org/0000-0002-4454-2317
}

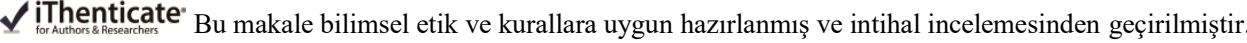

Atıf (APA 6)/To cite this article

Özbey, V. (2020). UNESCO Dünya miras listesi ve UNESCO geçici listelerinde köprü mirası ve Türkiye UNESCO geçici listesine yönelik öneriler. Atatürk Üniversitesi Güzel Sanatlar Enstitüsü Dergisi, 26(44), 258-268. doi: https://doi.org/10.35247/ataunigsed.663100
\end{abstract}

Makale Gönderim Tarihi/Received: 23/12/2019

Makale Kabul Tarihi/Accepted: 06/03/2020

Makale Yayın Tarihi/Published: 19/03/2020

Research Article / Araștırma Makalesi

\section{$\ddot{\mathbf{O z}}$}

Taşınmaz kültürel miras koruma yöntemleri geliștikçe korumaya değer görülen mimarî ürün yelpazesi de genişlemektedir. Korumada bir zamanlar arka planda tutulan, atıl durumdaki köprü mirasları, kendilerine verilen değerin artması ile birlikte UNESCO Dünya Miras Listesi'ne salt bir değer olarak kayıt ettirilen varlıklara dönüșmüștür. Calıșmada köprü mirasına verilen değerdeki artış, Dünya Miras Listesi'ne kayıt ettirilen köprü varlıkları incelenerek ortaya konulmuştur. Çalışma sonucunda köprülerin 2005 y1lı ile başlayan Dünya Miras Listesi'ne kayıt ettirilme faaliyetlerine yönelik gösterilen gayretlerin y1llar içerisinde arttığı, Dünya Kültürel ve Doğal Mirasının Korunmasına Dair Sözleşme'ye taraf devletlerin UNESCO geçici listeleri de taranarak tespit edilmiştir. Ortaya çıan bu yeni değer ile birlikte, her geçen y1l daha da kalabalıklaşan Dünya Miras Listesi ve taraf devlet geçici listeleri için yeni tedbirler alınmasının gerekli olduğu sonucuna varılmıştır. Türkiye UNESCO Geçici Listesi için ne gibi stratejiler uygulanabileceği tartışılmıştır.

Anahtar kelimeler: Türkiye UNESCO Geçici Listesi, Köprü Mirası, Kültürel Varlık, Geliştirme Stratejileri

\begin{abstract}
With the development of immovable cultural heritage preservation methods, the range of architectural products that are considered worth preserving is expanded. In the past years, idle bridges heritage, which has not been sufficiently attach importance to, has been transformed into singly assets offered to the UNESCO World Heritage List with increasing importance. In the study, the increase in the value given to the bridge heritage was demonstrated by examining the bridge assets registered in the World Heritage List. As a result of the study, it has been determined that efforts to register the bridges to the World Heritage List, which started in 2005, have increased over the years by analyzing UNESCO tentative lists of the States Parties to the Convention on the Protection of the World Cultural and Natural Heritage. With this new value, it is concluded that new preventions are necessary for World Heritage List and Tentative Lists of States Parties that increase every year. Feasible strategies for Tentative List of Turkey are discussed.
\end{abstract}

Keywords: Tentative List Of Turkey, Bridge Heritage, Cultural Asset, İmprovement Strategies

\section{Giriş}

İnsanın ulaşımda sınır tanımayan doğası, yaptığı araçlarla önüne çıkan engelleri kolayca aşmasına ve mevcut doğayı istediği şekle sokmasına olanak tanır. Köprü de bu araçların başında gelmektedir. Ancak dünya durağan bir yer değildir. Depremler, yanardağlar, erozyonlar, seller, dev dalgalar, firtınalar, yangınlar gibi çeşitli doğa olayları ile birlikte sürekli bir değişim ve dönüşüm içerisindedir. Bu karmaşık döngü içerisinde, insanın önüne çıkan engelleri aşmak için ürettiği yapılar, engeller yer değiştirdikçe işlevlerini yitirmektedir. Yatağı değişen bir nehir, eski yatağı üzerinde inşa edilen tüm köprüleri boşa çıkarmakta ve atıl duruma sokmaktadır. Üstelik böylesi bir değişim yaşanmasa bile zaman geçtikçe tarihî köprüler yıpranmakta ve müdahale edilmediğinde önemli bir çoğunluğu özgün yapım teknikleri ile ayakta kalamamaktadır.

Anadolu gibi dünyanın birçok bölgesinden daha fazla medeniyete ev sahipliği yapan, daha yoğun olaylara sahne olan bu topraklarda birçok mimarî eser türü üretilmiştir. Köprü de bunlardan birisidir. Eski medeniyetlerin yapı üretim kabiliyetleri hakkında kıymetli bilgiler veren, yapım tekniklerini, malzeme bilgilerini, konum seçim kriterlerini günümüze aktaran bu varlıklar, aynı zamanda mevcut coğrafyanın tarih içerisindeki farklı durumları hakkında da ipuçları vermektedir. Bu bilinç ile mimarî birer ürün olarak işlevini yitiren, kullanılmaz durumdaki köprülerin korunması büyük önem arz etmektedir. Asıl işlevini yitiren köprü miraslarından bazıları, kullanım hakkı şahıslarda bulunan tarlaların ortasında, bazıları ise hayvancılığın yaygın olduğu meralarda kalmış durumdadır. Bu tür yapıların korunmasında kullanılan yöntemlerden birisi de UNESCO Dünya Miras Listesi'ne (Liste; DML) başvurmaktır. Böylece varlığın uluslararası ortamda tanınırlığının artması ve yüksek oranda kültürel turist çekmesi hedeflenmektedir. 
Dünya Kültürel ve Doğal Mirasının Korunmasına Dair Sözleşme’ye taraf devletlerin bünyesinde, atıl durumda bulunan bu gibi varlıkların Liste'ye tek tek kaydettirilme çabası, taraf devlet UNESCO geçici listelerinde (geçici listeler) bir yığılmaya yol açmıştır. Bu sorun karşısında taraf devletler, geçici listelerinde yer alan varlıkları belirli sınıflar altında gruplandırarak geçici listelerini hafifletmeye çalışmaktadır. Böylece taraf devletler geçici listelerinde yer alan ortak bir başılı altında çok sayıda varlığı koruma altına almayı hedeflemektedir.

Geçici listelerde açık ara en fazla mirası bulunan Türkiye Cumhuriyeti Devleti de (2019 yılı) bu varlıklarını belirli sınıflandırmalar altında kümelemiştir. Bu bağlamda Türkiye UNESCO Geçici Listesi’nde bulunan ve gelecekte bunlara eklenmesi muhtemel köprü mirası ile ilgili uygulanabilecek geçici liste hafifletme stratejileri önerilmiştir. Türkiye UNESCO Geçici Listesi’nde yer alan köprü mirasları, kültürel birer varlık olarak daha önceki çalışmalarda ayrı ayrı detaylıca incelenmiştir. Çalışma, bu varlıkların UNESCO geçici listelerin tarihçesini, varlıkları yüzeysel olarak fakat üstün evrensel değer kavramı üzerinden açıklamaktadır. Çalışmanın bir diğer amacı da 21. yüzyılın getirdiği farkındalıkla anlamları daha da önemli hale gelen ve kendilerine verilen değerin arttığı köprü miraslarının DML'de artmaya başlayan önemine vurgu yapmaktır.

\section{Yöntem}

Nitel bir araştırma olan çalışmada UNESCO Dünya Miras Listesi'nin (Liste, DML) oluşturulduğu günden bugüne kadar Liste'ye dahil edilen kültürel ve karma miraslar incelenerek miraslar içerisinde yer alan köprü varlıkları tespit edilmiştir. Sınırları içerisinde bulunduğu taraf devletlerce tanımlanmış miras alanları içerisinde diğer varlıklarla ortak bir miras oluşturan ve miras içerisinde önemli bir yer tutan köprü kültürel varlıkları araştırılmıştır. Köprü yapı türünden kültürel varlıkların birer kültürel miras olarak Dünya Kültürel ve Doğal Mirasının Korunmasına Dair Sözleşme'ye taraf devletlerce ne zaman ve ne şekilde tanımlandığı incelenmiştir. DML'de kayıtlı bulunan köprü mirasları ile taraf devletlerin Liste'ye yazdırılmak üzere miraslarını sunabilmelerinin bir ön koşulu olan taraf devlet geçici listelerine alınan köprü mirasları birlikte ele alınarak, yapı malzemesi, yapım yöntemi, yapım yıll, toplam uzunluğu ve köprüyü bir miras olarak sahiplenen taraf devletler bakımından karşılaştırılmıştır. Köprülerin tek başlarına birer değer olarak tanımlanması tartışılmıştır. Türkiye UNESCO Geçici Listesi'ne 2015, 2016 ve 2018 yılında yazdırılan köprü mirasları incelenerek aktarılmıştır. Diğer taraf devletlerce uygulanan köprü miraslarına yönelik geçici liste stratejileri incelenerek Türkiye UNESCO Geçici Listesi için öneriler geliştirilmiştir.

\section{UNESCO Dünya Miras Listesi'nde köprü mirasları}

Mirasların kaydedilmeye başladığı 1978 yılından bu yana DML'ye birçok köprü varlığı dahil edilmiştir. Bunların birçoğu antik kentler ya da endüstriyel kasabalar gibi DML'de başka gerekçelerle bulunan mirasların bir bölümü olarak Liste'de yer almaktadır. Özellikle Liste'deki demiryolu, karayolu, suyolu güzergahları ile birlikte birçok köprü korunmaktadır. Bazı miraslarda ise ana vurgu, köprü varlığında olmasa da köprü, miras içerisinde çok büyük bir öneme sahiptir (Tablo 1).

Tablo 1

UNESCO Dünya Miras Listesi’nde bir miras içerisinde yer alan köprü varlıkları (UNESCO)

\begin{tabular}{|c|c|c|c|}
\hline DML'ye & rdiği Yıl & Taraf Devlet & Kriter \\
\hline Ironbridge Boğazı & 1986 & Birleşik Krallık & $1,2,4,6$ \\
\hline Avignon Tarihi Merkezi: Papalık Sarayı, Piskopos Topluluğu ve Avignon Köprüsü & 1995 & Fransa & $1,2,4$ \\
\hline Porto tarihi merkezi, 1. Luiz Köprüsü ve Serra do Pillar Manastırı & 1996 & Portekiz & 4 \\
\hline Tarihi Bridgetown ve Garnizonu & 2011 & Barbados & $2,3,4$ \\
\hline
\end{tabular}

Ancak Liste'ye tek başına köprü olarak giren, üstün evrensel değeri karşılayan varlıkları salt köprülerin oluşturduğu miraslar da vardır (Tablo 2). Kültürel bir varlık olarak köprünün bir değere sahip olması, 1990'lı yılların başında başlayan ve Yugoslavya Sosyalist Federal Cumhuriyeti'nin dağılışında en büyük yıkımın yaşandığı Bosna Savaşı sonucunda gerçekleşmiştir. Daha önceleri farklı kültürlerin bir arada barış içerisinde yaşayabileceğinin, kardeşliğin, çok kültürlülüğün sembolü olarak bilinen Mostar Köprüsü’ne, sırf bu taşıdığ1 anlamları yıkmak adına yapılan saldırılar sonucunda köprünün yıkılması ile birlikte taşıdığı bütün kültürel çeşitlilik vurgusu da yıkılmıştır. Yıkılan köprü bu harap durumu ile Bosna Savaşı'nın bir sembolüne dönüşmüştür (Morel, 2013, s. 6-7). Bosna-Hersek'in bir devlet olarak tanındığı 1995 yılından itibaren ise bağımsız bir devletin sembolü olmuştur. Bu kadar çok anlam taşıması onu tek başına bir değer yapmıştır. Bu sebeple Bosna-Hersek'in, 12 Temmuz 1993 tarihinde taraf olduğu Dünya Kültürel ve Doğal Mirasının Korunmasına Dair Sözleşme'ye dayanarak, UNESCO Dünya Miras Listesi’ne tanımladığı ilk mirası, yeniden yapımı 2004 yılında tamamlanan Mostar Köprüsü ve Tarihî Kent Merkezi olmuştur (Tablo 2). Daha önce 1 Eylül 1997 tarihinde, Bosna-Hersek UNESCO Geçici Listesi'ne Saraybosna mirası tanımlanmış olsa da ölçeği gereği mirasın yeniden yapım ve onarım çalışmalarının tamamlanması daha fazla zaman alacağı aşikârdır. Korunması için alınması gereken tedbirler de daha karmaşık ve zor olacaktır. 
Tablo 2

UNESCO Dünya Miras Listesi’nde (üstün evrensel değer taşıyan) köprü mirasları (UNESCO)

\begin{tabular}{lllrr}
\hline Kayıt Yılı & Miras & Ülke & Kriter & Varlık Alanı (Ha) \\
\hline 2005 & Tarihî Mostar Köprü Bölgesi & Bosna-Hersek & $\mathbf{6}$ & 7,6 \\
2006 & Vizcaya Köprüsü & İspanya & $\mathbf{1 , 2}$ & 0,9 \\
2007 & Sokullu Mehmet Paşa Köprüsü & Bosna-Hersek & $\mathbf{2 , 4}$ & 1,5 \\
2015 & Dördüncü Köprü & Birleşik Krallık & $\mathbf{1 , 4}$ & 12,4 \\
\hline
\end{tabular}

\section{Türkiye UNESCO Geçici Listesi'nde köprü mirasları}

Türkiye Cumhuriyeti Devleti, 1982 yılında taraf olduğu Dünya Kültürel ve Doğal Mirasının Korunmasına Dair Sözleşme'ye dayanarak, ilk olarak üç adet mirasını Dünya Miras Listesi'ne (DML) dahil ettiği 1985 yılından bu yana 18 adet mirasını DML'ye kayıt ettirmeyi başarmıştır (2019 yılı için). Gelecek yıllarda DML'de yer almasını istediği miraslarını da Türkiye UNESCO Geçici Listesi’ne yazdırmıștır. Sözleşme'ye taraf devlet UNESCO geçici listeleri, Dünya Miras Komitesi'nin DML'ye miras kabulü için bir ön koşuludur ve Sözleşme'ye taraf devletlerin miras envanteri olarak nitelendirilebilir. Ancak son on yılda Türkiye UNESCO Geçici Listesi'nde önemli derecede bir yığılma oluşmuştur. Geçici Listesi'nde yer alan 78 adet miras ile tüm Geçici Listeler arasında ilk sıraya yerleşmiştir ve bu durum, DML'ye dahil edilmek istenen miras alanları üzerinde yeni stratejiler oluşturmayı gerekli kılmaktadır (Özbey, 2019).

Tarihi çok eskilere dayanan bu coğrafyada yoğun bir kültürel miras birikimi vardır. Bu birikim içerisinde önemli yapı türlerinden birisi de köprülerdir. Türkiye UNESCO Geçici Listesi'ne bu birikimden üç adet köprü mirası tanımlanmıştır (2019 yılına kadar). Geçici listeye tanımlanan köprülerin tamamı geleneksel yöntemlerle inşa edilmiş taş yapılardır. Justinian Köprüsü, Geç Roma - Erken Bizans Mimarisi; Malabadi Köprüsü, Selçuklu Dönemi Mimarisi; Uzunköprü, Erken Dönem Osmanlı Mimarisi’ne örneklerdir (Tablo 3).

Tablo 3

Türkiye UNESCO Geçici Listesi’nde yer alan Köprü varlıklarının mimarî özellikleri [veriler: Uzunköprü (Atak, 2008; Özkök, Azsöz ve Erşan, 2015); Malabadi Köprüsü (Dalkılıç ve Halifeoğlu, 2009); Justinian Köprüsü (Özcan, 2015; Whitby, 1985) ]

\begin{tabular}{lccccrr}
\hline Miras & Uzunluk (m) & En Geniş Kemer Açıklığı (m) & En (m) & Yükseklik (m) & Yapım Yılı & Yansıttı̆̆ı Medeniyet \\
\hline Uzunköprü & 1392 & 14 & 5,50 & 14 & 1443 \\
Malabadi Köprüsü & 281,67 & 38,60 & 7,15 & 24,5 & Osmanlı \\
Justinian Köprüsü & 375 & 24,5 & 9,85 & 9 & Artuklu \\
\hline
\end{tabular}

Roma İmparatorluğu ile başlayan geleneksel yığma taş köprü yapım sistemi, nehrin karakterine göre farklı tekniklerin kullanılmasını gerekli kılmaktadır. Akarsu derinliğinin fazla olduğu, su seviyesinde mevsimsel farklarının büyük olduğu; geçiş noktasında akarsu yatağının dar olduğu; su akış hızının yüksek olduğu durumlarda tercih edilen teknik, tek gözlü köprüler olmuştur (Tanyeli, 2002, s. 231-232). Bu yapım tekniğinde amaç köprünün taşıyıcı ayaklarının akan suya basmaması ya da olabildiğince az miktarda basmasıdır. Tek göz kemer açıklığı büyük mesafelere ulaşabilmektedir. Yapımı çok zordur. Ana göze ek olarak yapının masifliğini kırmak adına hafifletme ya da taşkın gözleri de kullanılır. Akarsu yatağının geniş olduğu stratejik noktalardaki geçişlerde ise çözülmesi gereken ilk problem köprünün su içerisinde zemine oturan temel problemidir. Zemin dayanımına göre farklı zorluklarda çözümler üretilse de asıl problem su içerisinde yapım faaliyetlerini yürütebilmektir. Bunun için de çalışma alanında kuru zemin hazırlanması gerekir. Geleneksel yapım tekniği çerçevesinde akarsu yatağında kuru çalışma ortamı üç şekilde oluşturulmuştur: Mevsimsel farklılıklarda su seviyesinin düşmesi ile birlikte yatakta doğal yollarla kuru zeminler açığa çıkması; çalışma süresi boyunca akarsu yatağının değiştirilmesi; köprü ayaklarının zemine oturduğu noktalarda suyun tahliye edildiği havuz mantığı ile çalışan teknikler kullanılması.

Kuru zemin elde edildikten sonra ayakların oturacağı noktalarda zemin durumuna göre temel çalışmaları yürütülür. Suyun akış gücüne karşı ayakların zemine bağlanması genellikle birbirlerine bağlanan ahşap kazıklarla sağlanır. Ayrıca bu kuvvetin ayaklara zarar vermesini engellemek adına selyaranlar kullanılır. Taş malzemedeki dayanımı arttırmak adına parçalar arası sürtünme kuvvetini arttıran kesme taş sistemi kullanılır.

Edirne'nin Uzunköprü İlçesi’ne ismini veren Uzunköprü kültürel varlığı, kriter 3 ve kriter 4'ü karşıladığı gerekçesi ve 6042 referans numarası ile 2015 yılında Türkiye UNESCO Geçici Listesi'ne dahil edilmiştir. Öncesinde birçok aday dosyanın içerisinde diğer başka varlıklarla bir arada, köprü varlıkları koruma altına alınmış olsa da, bu adaylık dosyası ile birlikte ilk defa varlık olarak bir köprü tek başına Türkiye UNESCO Geçici Listesi’ne (Geçici Liste) yazdırılmıştır. Ertesi yıl bir başka köprü varlığı olan Malabadi Köprüsü (Diyarbakır), kriter 3, kriter 4 ve kriter 6'yı karşıladı̆̆ı gerekçesi ve 6113 referans numarası ile Geçici Liste'ye yazdırılmıştır. Bir yıl aradan sonra 2018 yılında yine bir köprü varlığı, Justinian Köprüsü (Sakarya), kriter 3 ve kriter 4'ü karşıladığı gerekçesi ve 6347 referans numarası ile Geçici Liste’ye dahil edilmiştir. 


\subsection{Uzunköprü}

Köprü, Edirne İli’nin Uzunköprü İlçesi’nde, Ergene Nehri üzerinde yer alır. Edirne Merkez'e 66 kilometre; Tekirdağ Merkez'e 92 kilometre; Kırklareli Merkez'e 84 kilometre mesafededir. Yapımı 1443 yılında, Sultan Murad Han döneminde tamamlanmıştır. Köprünün yapımı tamamlandığında yaklaşık $1392 \mathrm{~m}$ uzunluğunda olmalıdır (Edirne salnâmesi, 1309, s. 214). Ancak günümüzde yaklaşık $1240 \mathrm{~m}$ uzunluğu ayakta kalmıştır (Akçıl, 2012) ve bu uzunlukla kullanılmakta olan en uzun taş köprüdür. İlk yapıldığında köprünün adı Cisr-i Ergene olarak, 18. yüzyıldan itibaren bir müddet de Kasr-ı Ergene olarak kayıtlarda geçmektedir (Yüksel, Bülbül ve Gündüz, 2011, s. 28). Köprünün kemer bezemelerinde bitki ve hayvan figürleri, geometrik motifler ile palmetler göze çarpmaktadır ("Kültür Varlıkları”, 2015).

Köprü, Osmanlı İmparatorluğu, 15. yüzyıl Erken Osmanlı Dönemi eserlerindendir (Görsel 1). Yapımına 14261428 yıllarında başlanmış ve 1443 yılında sonlandırılmıştır (Akçıl, 2012, s. 266-267). Köprünün yapım kitabesi 150 x $70 \mathrm{~cm}$ boyutlarında mermerdendir ve iki satır halinde sülüs celî hat ile;

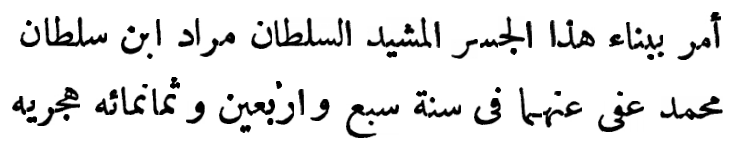

yazmaktadır (Çulpan, 2002, s. 99). Türkçe okunuşu Çulpan'dan (2002);

“ 'Amara bi-binā-i hāža 'l-cisri 'l-maşīd as-Sulțān

Muhammed 'afā 'anhuma fĩ sanati sab'a va arba‘īna va șamānami’a hicriya

$847(1443 / 1444) "$

şeklindedir. Meali ise;

“İnşa edilen bu köprüyü Allah günahlarını affeylesin Sultan Muhammed oğlu Sultan Murad hicri 847 y1lında emretmiştir” şeklindedir (Yüksel, Bülbül ve Gündüz, 2011, s. 28). Köprüde bulunan başka bir kitabeye göre 174 kemeri vardır. Ana gözün üzerinde bir köşk yer alır. Köprünün 40. ve 41. sıradaki kemerleri ile 102 . ve 103. sıradaki kemerleri arasında, birer seyir terası olduğu bilinmektedir (Akçıl, 2012; Yüksel, Bülbül ve Gündüz, 2011). Köprünün yapımında kullanılan kireçtaşı ve traverten cinsi ("Kültür Varlıkları", 2015) kesme taşlar, Yağmurca Köyü, Eskiköy ve Hasırcı Arnavut Köyü (Yunanistan) taşocaklarından karşılanmıştır (Çulpan, 2002). Balkas (1958), yapı malzemelerinin temini ile ilgili, “İnşa malzemesi olarak, Ergene’nin ötesindeki Eskiköy, Kuleliburgaz, Taşçıarnavut Köyleri ocaklarından getirilen taşlar Yayalar Köyü kenarında; Kestanbolu, Süleymaniye Köyleri ocaklarından getirilen taşlar da kasaba içinde, bu günkü Halise Hatun mahallesinde toplanarak yontulmağa ve köprüye yerleştirilmeğe başlanmıştır” ifadesini kullanmıştır. İlk temel çalışması Yayalar Köyü tarafında gerçekleştirilmiştir (s. 27).

Köprünün oturduğu zemin kil, kumtaşı, kumlu kil ve kumlu tüflerden oluşmaktadır (Yüksel, Bülbül ve Gündüz, 2011, s. 26). Köprü temellerinde enerji sönümleyici ahşap ızgara sistemi kullanılmıştır ("Kültür Varlıkları", 2015).

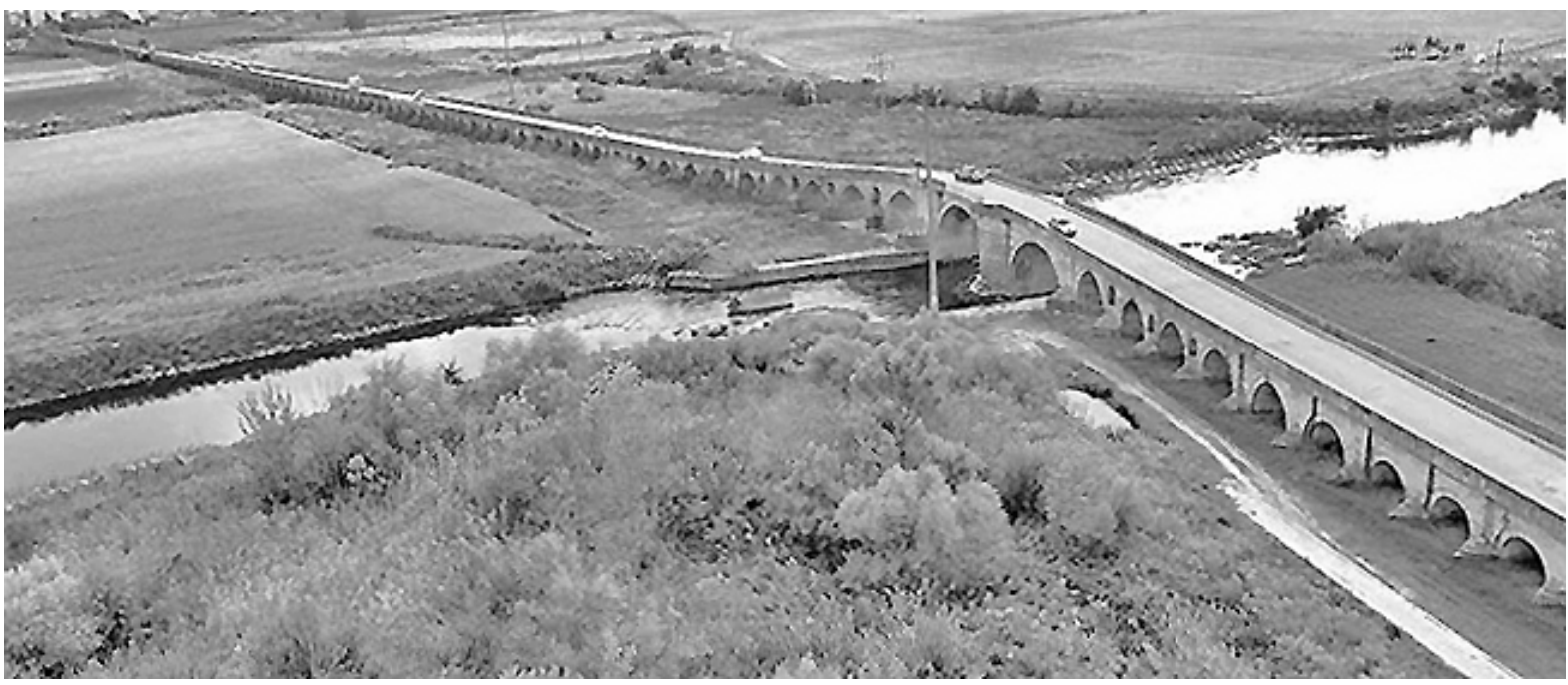

Görsel 1. Uzunköprü

Yapımı tamamlandıktan dört yıl sonra ilk onarımı, bölgesel bir onarım olarak yapılmıştır. Yapının daha kapsamlı onarımları Fatih Sultan Mehmet, II. Bâyezîd, Kanunî Sultan Süleyman, II. Osman, II. Mahmud ve II. 
Abdülhamid dönemlerinde gerçekleştirilmiştir (Akç1l, 2012; Yüksel, Bülbül ve Gündüz, 2011, s. 28-30). Cumhuriyet Dönemi’nde, 1928 yılında da bir onarım yapılmıştır. Miras üzerinde 1964-1971 yılları arasında yol genişletme çalışmaları gerçekleştirilmiştir (Yüksel, Bülbül ve Gündüz, 2011, s. 30).

\subsection{Malabadi Köprüsü}

Diyarbakır İli, Silvan İlçesi sınırları içerisinde yer alır. Diyarbakır ile Batman il sınırında, Dicle Nehri'ne bağlanan Batman Çayı üzerinde bulunan Batman Barajı'nın yaklaşık 500 metre güneyinde konumlanır. Batman merkez'e 30 kilometre; Siirt Merkez'e 89 kilometre; Diyarbakır Merkez'e 100 kilometre uzaklıktadır. Kitabesine göre H. 542 (M. 1147-1148) tarihinde, Timurtaş bin İlgazi bin Artuk tarafından yaptırılmaya başlanmış, onun vefatı üzerine oğlu Necmeddîn Alpî'nin Evkaf nazırlığına atadığı Zahid el-Tavıl tarafından 550 (M. 1155) yılında tamamlanmıştır (Beysanoğlu, 1990). Ana açıklık dahil toplam beş gözlüdür. Büyük orta kemer 40,86 metre açıklığı (kemer ayak aksları arası mesafe olarak, Elbir ve diğerleri, 2015, s. 87) ile ayakta kalan taş köprüler arasında geçilen en geniş açıklığa sahiptir. Yapımında horasan harcı kullanılan (AA, 2018) köprünün uzunluğu 238 metredir (Alkan ve diğerleri, 2011). Malabadi Köprüsü'nün tempan alanında odacıklar, helâ ve merdivenler bulunduğundan, güzergahtaki yolcular için bir dinlenme, bir konaklama yapısı işlevi de gördüğü anlaşılmaktadır (Halifeoğlu, Toprak ve Kavak, 2011, s. 29). Temellerinin sağlam zemine inşa edilmesi sebebi ile köprü, doğrusal değil açılı bir yol oluşturur (Elbir ve diğerleri, 2015, s. 82). Tek gözlü kemer olarak sınıflandırılabilecek köprünün iki yakasındaki kod farkı, ana gözün kilit taşına göre farklı eğimler verilerek çözülmüştür (Görsel 2). Eğimli köprü yolu basamaklanarak eğimin dikliği kırılmıştır.

Türkiye Cumhuriyeti'nin kültürel mirası açısından önemli bir bilgi kaynağı olan, 17. yüzyıl Evliya Çelebi Seyahatnamesi'nde (Dağlı ve Kahraman, 2001, s. 57), köprünün diğer köprüler arasında öne çıkan mimarî değeri şöyle tanımlanmıştır;

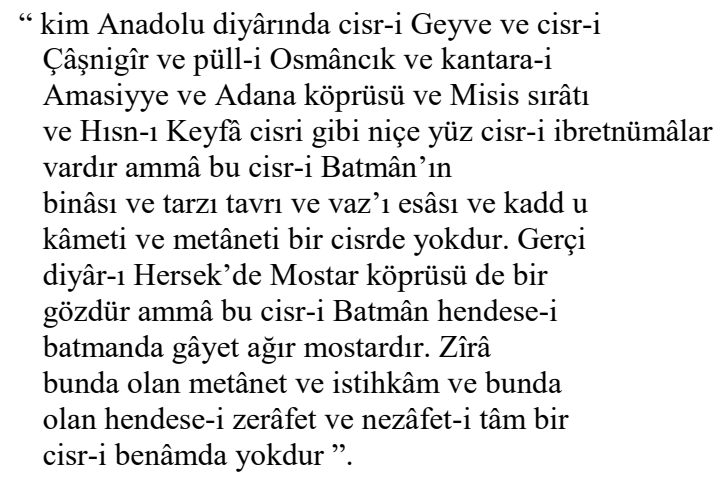

Köprü üzerinde insanların betimlendiği bir figür dikkat çekmektedir. Bu figürü Konyar (1936) şu şekilde ifade etmektedir; "İki insandan biri ayakta durmakta, diğeri oturmaktadır. Ayaktaki, oturana bir şey sunmakta, diğeri de ellerini uzatarak bunu alır bir durumdadır. Başlarında sivri uçlu birer külah vardır”, diğer yüzündeki figürler ise "... 1şınlar ile bir güneş, tam ortada bir insan ve güneşin altında da bir hayvan (aslan) vardır" (aktaran Çulpan, 2002, s. 42)

Ana kemer ayakları hizasında iki demir kapı bulunduğu ve geceleri kapılar kilitlenerek geçişin kapatıldığı bilinmektedir (Dağlı ve Kahraman, 2001, 57). Demir kapıların asıldığı taş malzemeden üretilmiş kapı yuvalarından batı yönünde olanı varlığını korumaktadır (Görsel 2).

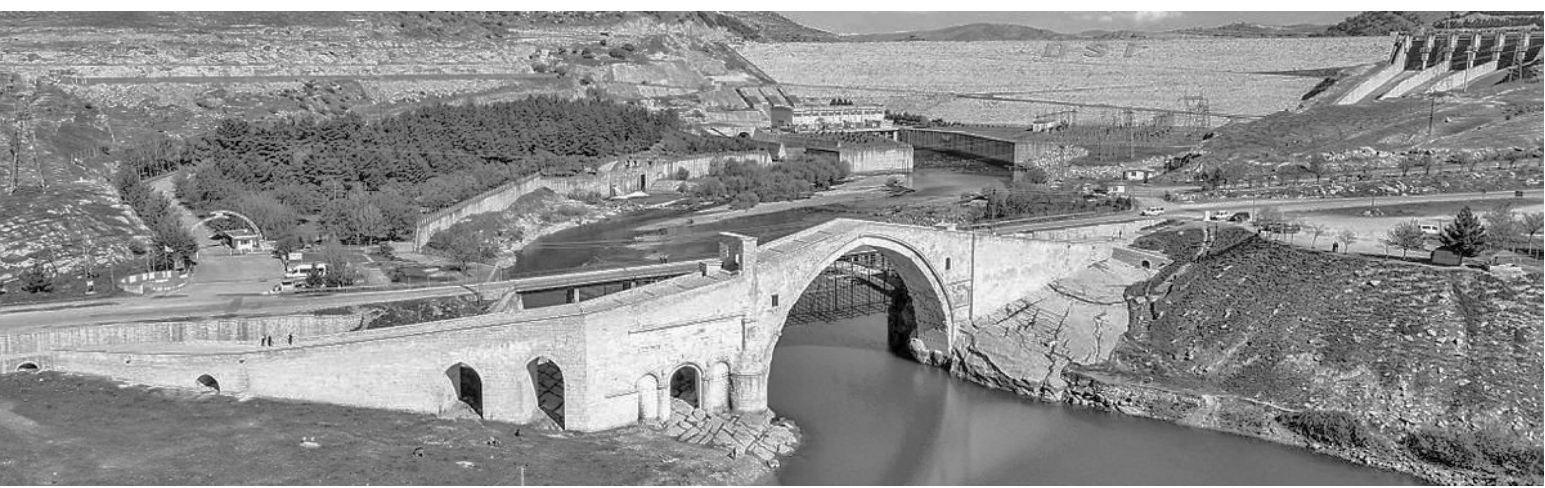

Görsel 2. Malabadi Köprüsü

Köprünün, Kurt İsmail Paşa ve Vali Faiz Bey dönemlerinde ve Karayolları Köprüler Servisi tarafindan 1930 yılında onarıldığı bilinmektedir (Çulpan, 2002, s. 42). Köprü üzerinde gerçekleştirilen 1954 ve 1985 tarihli 
onarımlarda, ana kemer karnı ve kemer tempan yüzeyleri dışındaki tüm dış yüzeyler, çimento esaslı sıva ile kaplanmıştır ve döşeme üzerine beton dökülmüştür (Elbir ve diğerleri, 2015, s. 83). Mirasın, 2009-2013 yılları arasında restorasyonu gerçekleştirilmiştir.

\subsection{Justinian Köprüsü}

Sapanca Nehri'nin fazla suyunu Sakarya Nehri'ne aktaran Çark Deresi (Antik Çă̆'da Melas) üzerinde, Sakarya İli, merkez Beşköprü Mahallesi'nde bulunur. Köprü, doğu-batı doğrultusunda uzanır. Yedi ana gözü vardır. Kuzeydoğu ucunda üç, güneybatı ucunda iki adet yan göz daha bulunur. On iki gözün tamamının kemerleri daireseldir. Köprü ana gözlerini sınırlayan kemer ara ayaklarının (altı adet) güney yüzleri dairesel, kuzey yüzleri üçgen planlıdır (Görsel 3). Köprünün gövde uzunluğu yaklaşık 357 metredir (Özcan, 2015, s. 2). Batı ucunda yer alan zafer takı ve doğu ucunda yer alan apsisli yapı da dahil edildiğinde yapının toplam uzunluğu artar ancak farklı kaynaklarda uzunluk, farklı ölçülerde verilmiştir ${ }^{1}$.

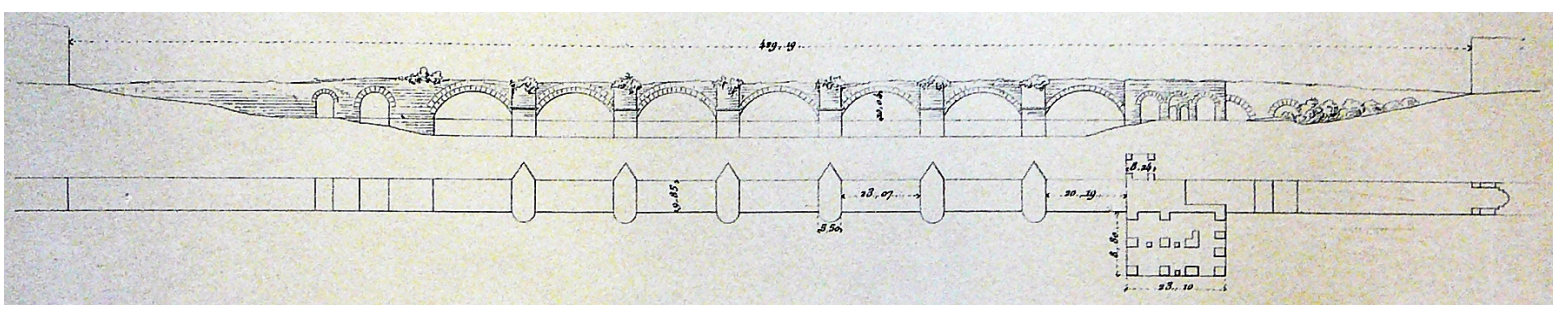

Görsel 3. Sangarius Köprüsü çizimi

Batı ucundan başlayarak beşinci göz kemerinin kilit taşında betimlenen haç figürü ${ }^{2}$, yapının Hristiyan-Bizans eseri olduğunu düşündürmektedir (Şahin, 2013, s. 6). Bu sebeple köprünün, 558-562 y1lları arasında Justinian

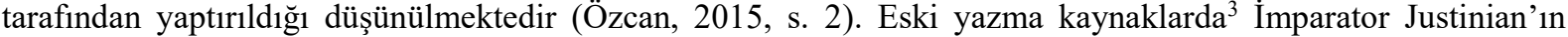
Sakarya Nehri üzerinde büyük bir köprü yaptırdığının geçmesi de bu tezi destekler niteliktedir. Bir zamanlar köprü üzerinde bulunan bir levhada Justinian Dönemi şairlerinden Agathias'ın şu mısraları yer almıştır (Şahin, 2013, s. 3);

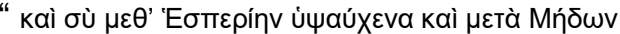

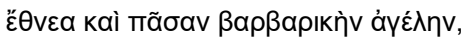

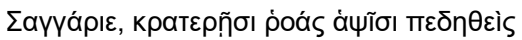

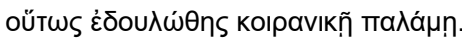

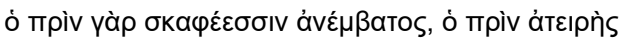

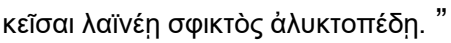

Şahin (2013, s. 4)'den çevirisi;

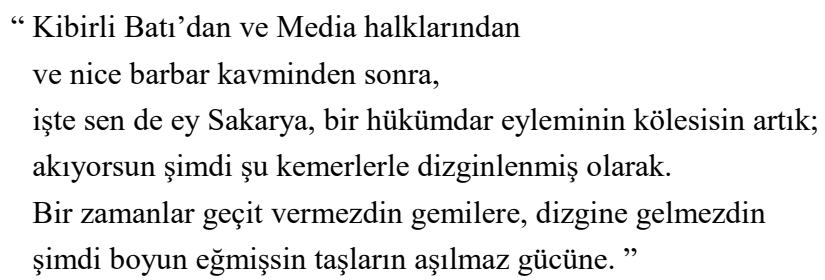

Ancak bahsi geçen köprünün bugün çalışmaya konu olan köprü olup olmadığı ile ilgili birçok tartışma konusu vardır ve kesin bir sonuç çıkarılabilmiş değildir. Bunlardan birisi günümüzde köprü Sakarya Nehri üzerinde değil, Çark Deresi (Melas Nehri) üzerinde bulunmasıdır. Bununla ilgili, Sakarya Nehri'nin sık sık taşkınlara sebep olduğu ve yatağını değiştirdiği, eskiçağlardan beri bilinmektedir. Örneğin, Justinian'ın bu taşkınları önlemek ve Sangarios Nehri'nin akış hızını kontrol altına almak için nehir yatağını değiştirdiği Paulus Diaconus'un, Historia Romana’sında geçmektedir. Köprünün altından geçen ve günümüzde yatağı değişmiş olan akarsuyun akış yönü de ayrı bir tartışma konusudur.

Bir diğer çelişki de eski yazılarda köprünün beş kemerli ya da su kontrol sisteminin beş köprülü olduğudur. Köprünün bulunduğu mevkii bugün dahi Beşköprü olarak geçmektedir. Fakat mevcut köprünün yedi ana kemeri

\footnotetext{
${ }^{1}$ Özcan, 2015, s. 2'de 375 m; Whitby, 1985, s. 129'da 429 m; Kültür Varlıkları ve Müzeler Genel Müdürlüğü, 2018 'de 350 m; Türkiye Kültür Portalı, 2019'da 365 m; Alkan vd. 2011'de 335 m olarak geçmektedir.

${ }^{2}$ Whitby, 1985, s. 130'da köprüyü beş ana ve uçlarda iki ara gözlü olarak tanımlamıştır. Bu tanımına göre metinde geçen haç figüründen farklı olarak batıdaki ara kemerin (yedi ana gözden en batıdaki) kuzey yüzünde ve ona bitișik olan ilk ana kemerin (yedi ana gözden batı ucundaki ikincisi) güney yüzünde görülebilen haç figürlerinden bahsetmektedir ve köprünün yapıldığı dönemde yedi ana göz kemerlerinin tamamında, her iki yöndeki yüzlerinde de haç işaretlerinin bulunduğu görüşünü paylaşmaktadır.

${ }^{3}$ Konu hakkında ayrıntılı bilgi ve metinler için bkz. Şahin, 2013.
} 
vardır. Köprü olarak ise diğer dört köprü bilinmemektedir. Bu da akıllara varlığı unutulmuş başka bir köprüyü getirmektedir. Konu üzerine çalışan Şahin (2013), bu unutulmuş köprü ya da sistemin köprülerinden birisi olabilecek bir kalıntı tespit etmiştir. Araştırmacılar sadece, mevcut köprünün (Görsel 4) Justinian tarafından yaptırıldığı üzerinde birleşmektedir.

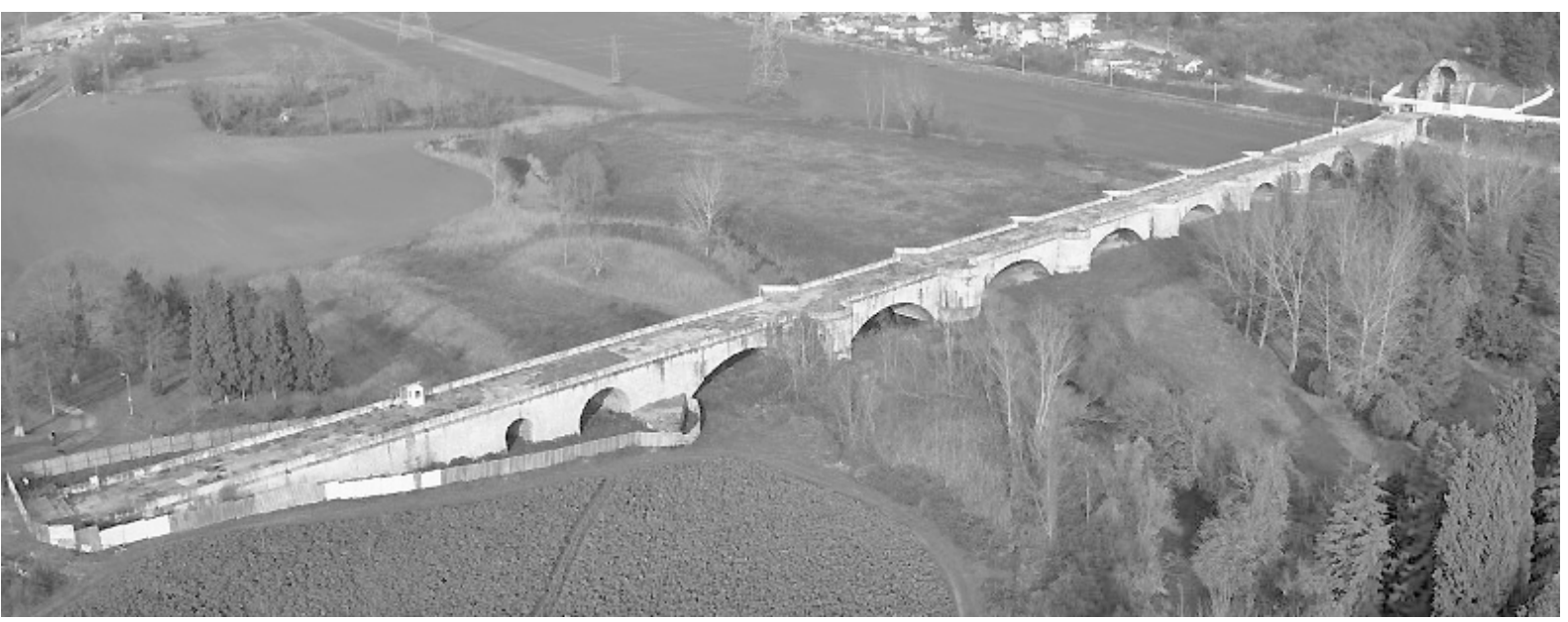

Görsel 4. Sakarya Justinian Köprüsü

Köprüde 1990-1995 yılları arasında Karayolları Genel Müdürlüğü tarafından onarım çalışmaları yürütülmüştür (Özcan, 2004). Çalışmaların sonlandığg 1995 yılında, taşıt trafiğine kapatılmıştır (Çetin, 2009, s. 90).

\subsection{Bölüm Sonucu Olarak}

Köprü varlığının bir dünya mirası olarak değerlendirilmesi ve DML'ye dahil edilmesi, Avrupa Kıtası'nda gerçekleşmiştir (Görsel 5). Diğer kitalarda yer alan taraf devletlerin girişimleri olsa da bu çabalar geçici liste seviyesinde kalmış ve varlıkların DML'ye dahil edilmesi adına ciddi girişimlerde bulunulmamıştır. Bu pencereden bakıldığında köprü kavramının anlam bulduğu bu coğrafya içerisinde Türkiye UNESCO Geçici Listesi'nde kayıtlı köprü miraslarının da DML'ye dahil edilme çabaları daha ciddi olacaktır. Ancak yine de DML'ye adaylık dosyasının sunulmasını bekleyen miras sırası çok kalabalıktır. Bu sebeple köprü mirası özelinde de bir adaylık birleştirme ya da uluslararası ortaklık anlaşmaları ile sınıraşan miras statüsünde adaylık ya da adaylıklar yararlı olacaktır.

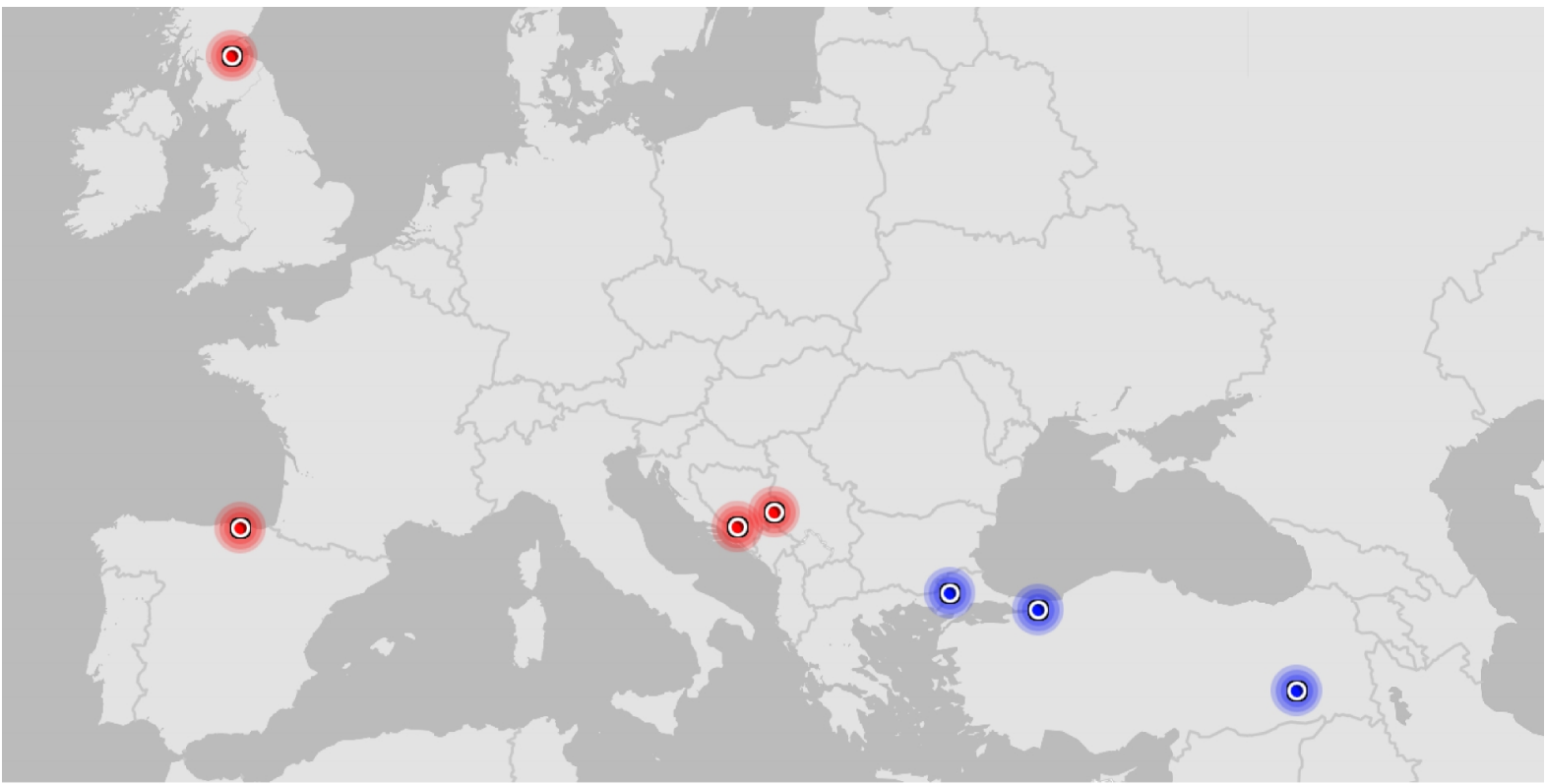

○ UNESCO Dünya Miras Listesi köprü mirasları

Türkiye UNESCO Geçici Listesi köprü mirasları

Görsel 5. UNESCO Dünya Miras Listesi’nde ve Türkiye UNESCO Geçici Listesi’nde köprü miraslarının coğrafî dağılımı 


\section{Sözleşme’ye taraf devletlerin UNESCO geçici listelerinde köprü mirasları}

Sözleşme'ye taraf devletlerin DML'ye yazdırmak istedikleri mirasları, Dünya Miras Merkezi'ne envanter olarak bildirdikleri taraf devlet UNESCO geçici listelerinde depolanır. Taraf devlet DML'ye sunmak istediği mirasını bu envanterden seçer. Bu bir ön koşuldur. Bu sebeple taraf devletin DML'ye dahil etmek istediği mirasları okumak mümkündür. Fakat bu geçici listelerde yer alan tüm mirasların dosya halinde Merkez'e sunulacağı anlamını taşımaz. Taraf devlet istediği miraslarını geçici listelerden çekebilir. Bunun sebebi Dünya Miras Komitesi'nden ret kararı alarak geri dönen adaylık dosyalarındaki mirasların tekrar Merkez'e sunulamıyor olmasıdır. Komite, ayrıca taraf devletlere en fazla on yıllık periyotlarla geçici listelerin kontrol edilerek yeniden düzenlenmesini tavsiye etmektedir.

Bu bağlamda taraf devletler UNESCO geçici listelerinde köprü miraslarının da (Tablo 4) araştırılması, taraf devletlerin DML ile ilgili gelecek stratejilerini anlamaya yardımcı olması açısından önemlidir. Geçici listelerde fazlaca bekleyen miraslar, devlet yönetimi zamanla değiştiğinden rafa kalkmaya daha yakındır. Hükümetler, izledikleri politikaları destekler nitellikteki varlıklara ağırlık vererek önce ülkenin geçici listesine daha sonra da DML'ye başvuruda bulunmaktadır. Tek başlarına kültürel turizm için bir çekim noktası oluşturmaları zor görünen köprü mirasları, bu kararlardan etkilenen varlıkların başında gelmektedir.

Şili’nin bir taraf devlet olarak 2019 yılı mevcut geçici listesinde yer alan 17 mirasından 14 adedini dahil ettiği 1998 yılında geçici listeye alınan Malleco Viyadügü’nün tek başına bir varlık olarak kabul edilmesi ile birlikte köprü mirasları, DML sürecinde var olmaya başlamıştır. Diğer tüm köprü miraslarının adaylıkları incelendiğinde bu tarih, erken bir tarihtir ve belli ki köprü kavramının bir miras olarak yeterli görülmesi için uygun ortam oluşmamıştır. Şili DML'ye dahil ettiği altı mirasından beşini 2000 yılı ve sonrasında sunmuştur. Ayrıca DML'de bulunan köprü miraslarının tamamı, Malleco Viyadüğü Şili UNESCO Geçici Listesi'ne alındıktan sonra Merkez'e sunulmuştur. Şili Cumhuriyeti'nin Dünya Miras alanları kriterlerinden kriter 1 ve kriter 4'ün karşılandığı gerekçe gösterilerek 1199 referans numarası ile geçici listesine aldığı miras, 21 yıldır DML'ye sunulmayı beklemektedir.

İran İslâm Cumhuriyeti, 05 Şubat 2008 tarihinde Luristan Eyaleti’nde bulunan on bir adet Sasanî Dönemi tarihî köprü mirasını Tarihî Köprüler Kolleksiyonu başlığg altında, kriter 1, kriter 2 ve kriter 3'ü karşıladığı gerekçesi ve 5273 referans numarası ile İran UNESCO Geçici Listesi’ne yazdırmıştır.

Kolombiya Cumhuriyeti, Batı Antioquia'sında bulunan, Olaya ve Santa Fe de Antioquia'yı birbirine bağlayan asma köprüsünü Puente de Occidente (Batı Köprüsü) olarak isimlendirerek 27 Eylül 2012 tarihinde kriter 1 ve kriter 4'ü karşıladığ 1 gerekçesi ve 5772 referans numarası ile geçici listesine yazdırmıştır.

Amerika Birleşik Devletleri'nin New York şehrinde bulunan, East River üzerinde Brooklyn ile Manhattan'ı birbirine bağlayan Brooklyn Köprüsü, kültürel bir miras olarak kriter 2 ve kriter 4'ü karşıladığ gerekçesi ve 6232 referans numarası ile 12 Nisan 2017 tarihinde ABD UNESCO Geçici Listesi'ne alınmıştır.

Türkiye Cumhuriyeti, 2015 yılında Edirne'nin Uzunköprü İlçesi’ne ismini veren Uzunköprü kültürel mirası ile başlayan DML'de köprü miraslarının başvuru süreci 2016 yılında Diyarbakır ve Batman İlleri sınırında yer alan Malabadi Köprüsü ile devam etmiştir. Süreç 2018 yılında Sakarya İli Merkezi’nde, bir zamanlar Sakarya Nehri üzerinde bulunan Justinian Köprüsü ile devam etmiş ve Türkiye UNESCO Geçici Listesi'nde yer alan köprü varlıkları toplamı üçe ulaşmıştır.

Tablo 4

Sözleşme’ye taraf devletlerin UNESCO geçici listelerinde bulunan köprü mirasları (UNESCO)

\begin{tabular}{lllr}
\hline Kayıt Yıl & Miras & Taraf Devlet & Kriter \\
\hline 1998 & Malleco Viyadüğü & Şili & $\mathbf{1 , 4}$ \\
2008 & Tarihî Köprüler Koleksiyonu & İran & $\mathbf{1 , 2 , 3}$ \\
& Gavmishan Köprüsü & & \\
& Kalhor Köprüsü & \\
Kashkan Köprüsü & \\
Kasian Köprüsü & \\
Pol-e Dokhtar Köprüsü & \\
Poletang Köprüsü & \\
Shapouri Aleshtar Köprüsü & \\
Shapouri Kakareza Köprüsü & \\
2012 & Shapouri Khorramabad Köprüsü & & \\
2015 & Siahplleh Köprüsü & & \\
2016 & Zal Köprüsü & Kolombiya & $\mathbf{1 , 4}$ \\
2017 & Puente de Occidente & Türkiye \\
2018 & Uzunköprü & Türkiye & $\mathbf{3 , 4}$ \\
& Malabadi Köprüsü & ABD & $\mathbf{3 , 4 , 6}$ \\
& Brooklyn Köprüsü & Türkiye & $\mathbf{2 , 4}$ \\
& Justinian Köprüsü & & $\mathbf{3 , 4}$ \\
\hline
\end{tabular}




\section{Tartışma}

Şili'de bulunan Malleco Viyadüğü'nün üstün evrensel değer taşıdığının gerekçelendirildiği 1998 yılında Şili UNESCO Geçici Listesi'ne alınması, konu üzerinde başlayan tartışmalar ve farkındalık hakkında bilgi sunmaktadır. Ancak DML'ye ilk dahil olan köprü mirası 2005 yılında Tarihî Mostar Köprü Bölgesi başlıklı dosya ile Mostar Köprüsü olmuştur. Dünya Miras Listesi’nin oluşturulduğu 1978 yılından itibaren uzun bir süre köprülerin tek başlarına bir değer olarak görülmemesi, onlara yüklenen anlamdan dolayıdır. Üstün evrensel değer kavramı bir mirasın taşıdığı değerle değil ona yüklenen anlamla ilgilidir. Yugoslavya Sosyalist Federe Cumhuriyetleri dağılmaya başlayana kadar barışın ve birlikteliğin bir sembolü olan Mostar Köprüsü, dağılış yıllarında saldırıya uğradığı 8 Kasım 1993 gününün ertesi günü saat 10:16’da yıkılarak savaşın bir sembolüne dönüşmüştür. Bağımsızlığını kazanarak yaralarını saran Bosna-Hersek’te, onarımı yapılan Mostar Köprüsü, bağımsızlığın ve iyileşmenin sembolü olmuştur. Her seferinde anlam değiştirse de bir ulusun kimlik inşasında vazgeçilmez bir yere sahip olduğu bir gerçektir. Üzerine yüklenen bu kadar çok anlamdan olsa gerek hem Bosna-Hersek'in DML'ye dahil edilen ilk mirası hem de DML'de yer alan ilk köprü mirası olmuştur.

Bu tarihten sonra 2006, 2007 yıllarında birer köprü mirası daha DML'ye alınmıştır. İran, 2008 yılında Tarih $\hat{\imath}$ Köprüler Kolleksiyonu başlığı altında on bir adet Sasanî Dönemi taş köprüsünü geçici listesine yazdırmıştır. Bu gelişmelerden sonra iki - üç yıllık bir boşluk oluşmuştur. Kuzey İskoçya'da bulunan ve açıldığı 1890 yılında dünyanın en büyük açıklık (541 metre) geçen köprüsü unvanını taşıyan Dördüncü Köprü (The Fourth Bridge) için adaylık sürecini başlatma çalışmaları 2010/2011 yıllarında hızla gerçekleştirilmiş ve köprü DML'ye sunulmak üzere Birleşik Krallık UNESCO Geçici Listesi'ne eklenmiştir. Bu süreç devam ederken 2012 y1lında Kolombiya, iki yaya, bir araç yolundan oluşan ve Cauca Nehri'nin iki yakasını birleştiren Puente de Occidente'yi (Batı Köprüsü) geçici listesine almıştır. Süreci hızlı bir şekilde başarıyla tamamlanan Dördüncü Köprü, DML’ne alındığı sırada Türkiye Cumhuriyeti, Uzunköprü varlığını geçici listesine dahil etmiştir. Taraf devlet olarak Türkiye Cumhuriyeti Devleti 2016 yılında Malabadi Köprüsü ve 2018 y1lında Justinian Köprüsü'nü de Türkiye UNESCO Geçici Listesi'ne almıştır. Böylece DML’de yer alan dört köprü mirasının ikisinin sahibi konumundaki Bosna-Hersek'e rakip ya da ortak olacağını belli etmiştir. Amerika Birleşik Devletleri, Brooklyn Köprüsü’nü 2017 yılında geçici listesine yazdırmıştır. İran’ın tek bir miras adaylık dosyasında birleştirdiği on bir köprü varlığı da bir tarafa konulacak olursa DML'de ve geçici listelerde bulunan diğer köprü varlıkları ayrı taraf devletlerce kayıt ettirilmiştir.

Ancak bunun farkındalık için yeterli olmadığı görülmektedir. Çalışmada, 2005 yılında DML'de ve taraf devletlerin geçici listelerinde yer alan köprü mirasları (üstün evrensel değeri köprülerin karşıladığı) yapım dönemlerine ve tekniklerine göre incelenmiştir (Tablo 5).

Tablo 5

Yapım dönemlerine göre DML ve UNESCO geçici listelerinde yer alan köprü mirasları (UNESCO)

\begin{tabular}{|c|c|c|c|c|}
\hline Miras & Taraf Devlet & Uzunluk (m) & Malzemesi & Yapım Yılı \\
\hline \multicolumn{5}{|l|}{ GELENEKSEL } \\
\hline Tarihî Mostar Köprü Bölgesi & Bosna-Hersek & 28,6 & $\mathbf{T}$ & 1459 \\
\hline Sokullu Mehmet Paşa Köprüsü & Bosna-Hersek & 179,5 & $\mathbf{T}$ & $15 \ldots$ \\
\hline Tarihî Köprüler Kolleksiyonu & İran & Değişken & $\mathbf{T}$ & Değişken \\
\hline Uzunköprü & Türkiye & 1392 & $\mathbf{T}$ & 1443 \\
\hline Malabadi Köprüsü & Türkiye & 281,7 & $\mathbf{T}$ & 1148 \\
\hline Justinian Köprüsü & Türkiye & 350 & $\mathbf{T}$ & 560 \\
\hline \multicolumn{5}{|l|}{ MODERN } \\
\hline Vizcaya Köprüsü & İspanya & 160 & Ç, D & 1893 \\
\hline Dördüncü Köprü & Birleşik Krallık & 2529 & Ç & 1890 \\
\hline Malleco Viyadüğü & Şili & 347,5 & Ç & 1890 \\
\hline Puente de Occidente & Kolombiya & 291 & $\mathbf{A}, \mathbf{D}, \mathbf{C}$ & 1895 \\
\hline Brooklyn Köprüsü & $\mathrm{ABD}$ & 1825,5 & $\mathbf{C}$ & 1883 \\
\hline T: Taş $\quad$ Ç: Çelik & A: Ahşap & & & \\
\hline
\end{tabular}

Geleneksel yığma yapım teknikleri ile taş malzemeden üretilen köprüleri DML'ye aday gösteren taraf devletlerin, Müslüman çoğunluğa sahip olması dikkat çekicidir. Modern tarzda yapılan köprülerin tamamı 19. yüzyıl eserleridir. Modern tarzda üretilen köprülerde Çelik, Demir ve Ahşap malzeme kullanılmıştır.

\section{Sonuç ve Öneriler}

Dünya Miras Listesi’ne alınan köprü mirasları, 1990’lı yılların ortalarına kadar yakın çevresi ile veya içerisinde bulunduğu yerleşim birimi ile ele alınmıştır. Ayrı bir miras olarak köprülerin tanımlanması 2000'li yıllardan itibaren başlamış ve 2010 yılından sonra ivme kazanmıştır. Türkiye de köprü kültürel varlığı kavramının değerini diğer taraf devletlere nazaran daha erken fark etmiş ve 2015, 2016, 2018 yıllarında üç köprü mirasını geçici listesine kaydettirmiştir. 
İran, 2008 yılında Tarihî Köprüler Koleksiyonu başlı̆̆ı altında on bir adet köprü varlığını geçici listesine eklemiştir. Böylece gelecekte köprü mirasından kaynaklı geçici listesinde oluşacak bir birikim için erken tedbir almıştır. Özellikle Orta Doğu gibi birçok medeniyete ev sahipliği yapmış olan coğrafyalardaki taraf devletlerin geçici listeleri için bu başarılı bir stratejidir. Bu şekilde aynı yıl içerisinde çok sayıda varlık Dünya Miras Listesi'ne dahil edilebilmektedir. Dünya Miras Listesi için 2019 yılından itibaren taraf devletlerin sadece bir varlık sunabiliyor olması, yakın gelecek için bu stratejinin daha sık kullanılacağını düşündürmektedir.

Geçici listesi en kabarık taraf devlet olan Türkiye için bu gibi stratejiler önem arz etmektedir. Ancak Türkiye UNESCO Geçici Listesi’ne tanımlanmış köprü mirasları birbirinden farklı özellikler taşımaktadır. Üretildikleri dönem, köprü türü, çevreye uyum teknikleri, boyutları bakımından farklılıklar barındırmaktadır. Üç yapının da tek ortak noktası geleneksel yığma taş yapılar olmalarıdır. $\mathrm{Bu}$ da ortak başlık altında bir adaylık dosyası hazırlamak için pek yeterli görünmemektedir. Dolayısı ile İran'ın uygulamış olduğu stratejiden farklı stratejiler uygulanmalidir.

Uluslararası işbirliği kurularak sınıraşan statüsünde bulunan ortaklıklar geliştirmek akla yatkındır. Özellikle Bosna-Hersek gibi Osmanlı miraslarını Dünya Miras Listesi'ne sunma konusunda kararlı olan taraf devletlerle yapılacak anlaşmalar sonucunda Türkiye Cumhuriyeti topraklarında bulunan Osmanlı köprü mirasları ortak bir başlık altında tek dosya haline getirilebilir. Türkiye UNESCO Geçici Listesi'nde yer alan köprü miraslarından Uzunköprü, Bosna-Hersek'in Liste'de yer alan köprü mirasları ile aynı devir temsilcileri olmalarından dolayı mimarî olarak önemli ölçüde benzerlikler gösterir. Sakarya Justinian Köprüsü, benzer örneklerinin çokluğuna rağmen Liste'de benzer bir örneği yoktur. İran'ın Tarihî Köprü Koleksiyonunda yer alan köprüler, devir olarak yapıya en yakın olanlardır. Ancak İran örneklerini üreten Sasanîler olduğundan tam bir benzerlikten söz edilemez. Justinian Köprüsü ile aynı dönem temsilcisi köprüler Anadolu'da çok bulunduğundan gelecek adaylıklar için ilk örnek olması bakımından önemlidir. Malabadi Köprüsü, geçtiği geniş açıklık sebebi ile yine Mostar Köprüsü ile benzerlikler gösterir. İki eserin üretilmesinde de Türk kültürü önemli bir etkiye sahiptir.

Bu değerlendirmeler 1şı̆̆ında, Türkiye UNESCO Geçici Listesi’nde yer alan Uzunköprü ve Malabadi Köprüsü, Bosna-Hersek'in Liste'de yer alan köprü mirası ile Türk-İslâm eseri vurgusu altında ortak bir başlıkta birleştirilebilir. Böylece daha kısa zamanda daha çok sayıda Selçuklu-Osmanlı eseri köprü mirasının Dünya Miras Listesi'ne alınması sağlanabilir.

Sakarya Justinian Köprüsü için, adaylık dosyası başlığında Antik Dönem vurgusu yapılması, Türkiye'nin açacağı yeni bir dosyada birçok aynı dönem mimarî eserini tek çatı altında toplayabilmesine yardımcı olacaktır. Böylece birçok eserin korunmasına ve kültür turizmine destek olmalarına imkân tanınmış olur.

\section{Kaynakça}

Akç1l, N. Ç. (2012). Uzunköprü. Türkiye Diyanet Vakfı İslâm ansiklopedisi (Cilt 42, s. 266-267) içinde. Ankara: Türkiye Diyanet Vakfi, İslâm Araştırmaları Merkezi.

Alkan, A., Baykan, O., Atalay, A., Baykan, N., \& Öziş, Ü. (2011, Eylül). Su yapısı olarak Anadolu'daki taş köprüler. II. su yapıları sempozyumu bildiriler kitabı (s. 13-24) içinde. Diyarbakır: TMMOB İnşaat Mühendisleri Odası.

Atak, E. (2008). Erken Osmanlı köprüleri (Yüksek lisans tezi). YÖK tez veri tabanından erişildi (Tez No. 220477).

Balkas, İ. H. (1958). Tarihte Ergene ve Uzunköprü. Edirne: Uzunköprü Öğretmenler Derneği Yayını, Yeni Matbaa.

Beysanoğlu, Ş. (1990). Malabadi köprüsü. Anıtları ve kitabeleri ile Diyarbakır tarihi, 1.cilt (s. 343-346) içinde. Ankara: Diyarbakır Belediyesi Yayınları.

Çetin, Y. (2009). Köprüler: Beşköprü (Jüstinyen Köprüsü). Sakarya’nın kültürel ve tarihi mirası (s. 88-96) içinde. İstanbul: Melisa (Sakarya İl Kültür ve Turizm Müdürlüğü).

Çulpan, C. (2002). Türk taş köprüleri: Ortaçağdan Osmanlı devri sonuna kadar (2. baskı). Ankara: Türk Tarih Kurumu Basımevi.

Dağlı, Y., \& Kahraman, S. A. (Ed.). (2001). Evliya Çelebi Seyahatnamesi Topkapı sarayı kütüphanesi Bă̆dat 305 numaralı yazmanın transkripsiyonu-dizini, 4. Kitap. İstanbul: Yap1 Kredi Yayınları.

Dalkılıç, N., \& Halifeoğlu, F. M. (2009, Mayıs). Diyarbakır merkez ve ilçelerinde yer alan tarihi köprüler. $I$. uluslararası nebiler, sahabiler, azizler ve krallar kenti Diyarbakır sempozyumu bildiriler kitabı (s. 369-381) içinde. Diyarbakır: T.C. Diyarbakır Valiliği Kültür ve Sanat Yayınları.

Edirne Salnâmesi (Salnâme-i Edirne) 1309 (1891-92). Def’a XIX. Edirne: Edirne Vilayet Matbaas1. 
Elbir, M., Sert, H., Yılmaz, S., Partal, E. M., Demirci, H., Avşin, A., Nas, M., \& Turan, G. S. (2015, Mayıs). Tarihî Malabadi (Batman Su) köprüsü'nde yürütülen restorasyon-konservasyon çalışmaları. 3. köprüler viyadükler sempozyumu bildiriler kitabı (s. 81-91) içinde. Bursa: İnşaat Mühendisleri Odası, Bursa Şubesi.

Halifeoğlu, F. M., Toprak, Z. F., \& Kavak, O. (2011, Eylül). Tarihi Diyarbakır köprülerinin mimari, hidrolojik ve jeolojik açıdan değerlendirilmesi. II. su yapıları sempozyumu bildiriler kitabı (s. 25-42) içinde. Diyarbakır: Mattek Matbaacılık.

Konyar, B. (1936). Diyarbekir: Tarihi, kitabeleri, yıllı̆̆ı. Ankara: Ulus Basımevi.

Kültür Varlıkları ve Müzeler Genel Müdürlüğü (2015). Uzunköprü (Edirne) [2015]. T.C. Kültür ve Turizm Bakanlığ1. Erișim adresi: https://kvmgm.ktb.gov.tr/TR-137903/uzunkopru-edirne-2015.html

Kültür Varlıkları ve Müzeler Genel Müdürlüğü (2018). Justinianus Köprüsü (Sakarya) [2018]. T.C. Kültür ve Turizm Bakanlığı. Erişim adresi: https://kvmgm.ktb.gov.tr/TR-210800/justinianus-koprusu-sakarya2018.html

Morel, A. F. (2013). Identity and Conflict: Cultural Heritage, Reconstruction and National Identity in Kosovo. Architecture_Media_Politics_Society,3(1), 1-21.doi: 10.14324/111.444.amps.2013v3i1.001

Özbey, V. (2019, Ekim). UNESCO Dünya mirası geçici listeleri'nde yığılmalar ve Türkiye geçici listesi için öneriler. Çukurova 3. uluslararası bilimsel araștırmalar kongresi bildiriler kitabı (s. 12-21) içinde. Adana: ISPEC Uluslararası Yayınevi.

Özcan, Z. (2004). Tarihi Sangarius (Sakarya) köprüsü üzerine bir çalışma. 6. uluslararası inşaat mühendisliğinde gelişmeler kongresi’nde sunulan bildiri. Boğaziçi Üniversitesi, İstanbul.

Özcan, Z. (2015, Mayıs). Tarihi Sangarius köprüsünde hasar belirlenmesi ve güçlendirme önerileri. 3. köprüler viyadükler sempozyumu (s. 253-264) içinde. Bursa: TMMOB İnşaat Mühendisleri Odas1.

Özkök, M. K., Azsöz, G., \& Erşan, Ş. (2015, Mayıs). Erken ve Klasik Dönem (14.-17. yy) Osmanlı köprülerinin tarihsel gelişimlerinin ve yapım tekniklerinin incelenmesi: Edirne/Uzunköprü örneği. 3. köprüler viyadükler sempozyumu (s. 129-142) içinde. Bursa: TMMOB İnşaat Mühendisleri Odası.

Şahin, S. (2013). Iustinianus'un Bithynia'da Sakarya nehri üzerinde inşa ettirdiği köprü ve kanal tesisleri (N. E. Akyürek Şahin, Çev.). A. V. Çelgin ve N. E. Akyürek Şahin (Ed.), Eskiçağ Yazıları 4. Cilt: Akron 6 (s. 1-29) içinde. İstanbul: Arkeoloji ve Sanat Yayınları.

Tanyeli, G. (2002). Türkiye köprüleri. Türkler ansiklopedisi (Cilt:12, s. 231-241) içinde. Ankara: Yeni Türkiye Yayınları.

Türkiye Kültür Portalı (2019). Justinianus Köprüsü - Sakarya, T.C. Kültür ve Turizm Bakanlığı. Erişim adresi: https://www.kulturportali.gov.tr/turkiye/sakarya/gezilecekyer/justinianus-koprusu

UNESCO. (2020). Dünya miras merkezi. Erişim adresi: whc.unesco.org

Whitby, M. (1985). The Sangarius bridge and Procopius. The Journal of Hellenic Studies, 105, 129-148.

Yüksel, F. A., Bülbül, A. H., \& Gündüz, M. (2011). Uzunköprü (Cisr-i Ergene). Restorasyon ve Konservasyon Çalışmaları Dergisi, 7, 26-40.

\section{Görsel Kaynakçası}

Görsel 1. Doğan Haber Ajansı (2019). Uzunköprü [Fotoğraf] (işlenerek). Erişim adresi: https://www.hurriyet.com.tr/yerel-haberler/edirne/uzunkopru/catlaklar-olusan-tarihi-uzunkopru-icin-korumat-41109987

Görsel 2. Silvan Belediyesi (2019). Malabadi Köprüsü [Fotoğraf] (ișlenerek). Erișim adresi: https://silvan.bel.tr/silvanda-yasam/tarihi-eserlerimiz/malabadi-koprusu

Görsel 3. Texier, C. (1838). Sangarius Köprüsü Çizimi [Mimarî çizim] (işlenerek). Erişim adresi: https://www.wikiwand.com/tr/Justinianus_K\%C3\%B6pr\%C3\%BCs\%C3\%BC, Özgün basım: de Laborde, L. (1838). Voyage de l'Asie mineure. Firmin Didot Frères.

Görsel 4. Adayorum (2018). Sakarya Justinian Köprüsü [Fotoğraf] (işlenerek). Erişim adresi: http://www.adayorum.com/justinianus-koprusu-nde-heyecan-yaratan-calisma.html

Görsel 5. Earthstar Geographics, esri.com üzerinden coğrafî bilgi sistemi verileri ve whc.unesco.org üzerinden konum verileri kullanılarak yazar tarafından oluşturulmuştur. UNESCO Dünya Miras Listesi'nde ve Türkiye UNESCO Geçici Listesi’nde köprü miraslarının coğrafî dağılımı [Harita]. 